\title{
Effect of a mixture of conjugated linoleic acid isomers on growth performance and antibody production in broiler chicks
}

\author{
Kazuaki Takahashi $^{1} *$, Yukio Akiba ${ }^{1}$, Toshio Iwata $^{2}$ and Masaaki Kasai ${ }^{2}$ \\ ${ }^{1}$ Department of Animal Science, Faculty of Agriculture, Tohoku University, \\ Tsutsumidori-Amamiya-machi 1-1, Aoba-ku, Sendai-shi, 981-8555, Japan \\ ${ }^{2}$ Rinoru Oil Mills Co., Tokyo, Japan
}

(Received 10 September 2002 - Revised 13 November 2002 - Accepted 5 December 2002)

\begin{abstract}
The effect of dietary conjugated linoleic acid (CLA) isomers mixture on antibody titres against sheep blood erythrocytes (SRBC) and immunoglobulin (Ig) G concentration in plasma was studied in broiler chickens. In experiment 1 , male and female broiler chicks (11 d of age, Cobb strain) were fed a diet supplemented with $10 \mathrm{~g}$ CLA or $10 \mathrm{~g}$ safflower-seed oil $/ \mathrm{kg}$ diet for 2 weeks. An SRBC suspension $(5: 100, \mathrm{v} / \mathrm{v})$ in a phosphate buffer was intravenously injected at $18 \mathrm{~d}$ of age and a blood sample was taken from the wing vein at $25 \mathrm{~d}$ of age. Chicks fed the CLA-supplemented diet had enhanced first antibody titres in plasma to SRBC as compared with those fed the safflower-seed oil-supplemented diet, irrespective of sex differences. In experiment 2, male broiler chicks ( $8 \mathrm{~d}$ of age, Ross strain) were fed a basal diet or a diet containing $10 \mathrm{~g}$ CLA $/ \mathrm{kg}$ diet for 3 weeks. CLA in the CLA diet partially replaced the soyabean oil in the basal diet. The SRBC suspension was intravenously injected at 15 and $25 \mathrm{~d}$ of age and a blood sample was obtained at 21 and $29 \mathrm{~d}$ of age. The first antibody titres against SRBC were higher in chicks fed the CLA diet than those in chicks fed the basal diet, but the second titres were not. Plasma IgG concentrations in chicks fed the CLA diet were higher than those in chicks fed the basal diet on both sampling days. The results showed that dietary CLA enhanced antibody production in broiler chickens.
\end{abstract}

Dietary conjugated linoleic acid: Antibody production: Growth: Broiler chickens

Conjugated linoleic acids (CLA) are an isomeric mixture of $18: 2$ fatty acids that have conjugated double bonds (Fritsche $\&$ Steinhart, 1998). There is great interest in these fatty acid isomers because CLA have several unique proprieties that control physiological and metabolic responses, for example, anti-hypercholesterolaemic and anti-atherogenic effects in rabbits and hamsters, inhibition of cancer cell proliferation in vitro, suppression of mammary tumours in mice, and increased immune responses. These effects of CLA in animals have been reviewed by Fritsche \& Steinhart (1998) and Pariza et al. (2000, 2001). CLA also have great impact on growth performance and lipid metabolism in rats, mice and pigs (Chin et al. 1994; Dugan et al. 1997; Park et al. 1997; West et al. 1998; DeLany et al. 1999; Ostrowska et al. 1999; Stangl, 2000), but the effect appears to be less effective in chickens (Szymczyk et al. 2001; Du \& Ahn, 2002). It has also been suggested that CLA protects the catabolic responses against endotoxin in chicks and mammals (Cook et al. 1993; Miller et al. 1994; Takahashi et al. 2002). Although some studies in mammals suggest that
CLA affects certain aspects of the immune response such as lymphocyte proliferation (Chew et al. 1997; Wong et al. 1997) and interleukin-2 production in mice (Hayek et al. 1999), the effects on antibody production are not clear. Dietary CLA enhanced immunoglobulin (Ig) production in immunocompetent organs and plasma IgG concentration in rats (Sugano et al. 1998). Yamasaki et al. (2000) observed that CLA enhanced Ig production in spleen but did not affect serum IgG levels in rats. Cook et al. (1993) showed that antibody production to sheep blood erythrocytes (SRBC) was not affected by feeding CLA in chicks. Therefore, the effect of dietary CLA on antibody production in broiler chickens was evaluated in the present experiment.

\section{Materials and methods \\ Animals, diets and immune stimulation}

In experiment 1 , twenty each of male and female chicks ( $11 \mathrm{~d}$ of age, Cobb strain) were used and they were randomly

\footnotetext{
Abbreviations: CLA, conjugated linoleic acid; Ig, immunoglobulin; SRBC, sheep blood erythrocytes.

* Corresponding author: Dr Kazuaki Takahashi, fax +81 22717 8691, email taka@bios.tohoku.ac.jp
} 
assigned to two groups of twenty chicks (ten male and ten female), five replicates of two chicks in a cage. The birds were fed a commercial diet supplemented with $10 \mathrm{~g}$ safflower-seed oil or $10 \mathrm{gtCLA} / \mathrm{kg}$ diet for $14 \mathrm{~d}$ ad libitum. The commercial broiler chick diet $(21 \mathrm{~g}$ crude protein, $2 \mathrm{~g}$ crude fat and $12.8 \mathrm{MJ}$ metabolizable energy $/ \mathrm{kg}$ diet) mainly consisted of maize, soyabean meal, and maize gluten meal and satisfied the nutrient demand for broiler chicks (Japanese Feeding Standard for Poultry, 1997). The safflower-seed oil supplemented diet was considered as a basal diet in experiment 1 . At $18 \mathrm{~d}$ of age, $0.5 \mathrm{ml} \mathrm{SRBC}$ suspension $(5: 100, \mathrm{v} / \mathrm{v})$ in a $0 \cdot 01 \mathrm{M}$-phosphate buffer $(\mathrm{pH} 7 \cdot 2)$ was intravenously injected. A blood sample was obtained via the wing vein at $25 \mathrm{~d}$ of age. CLA used in the present experiment consisted of $46.6 \mathrm{~g}$ cis-9, trans-11/ trans -9 , cis- $11,48 \cdot 2 \mathrm{~g}$ trans- 10 , cis- $12,3 \cdot 2 \mathrm{~g}$ cis- 9 , cis-12/ cis-10, cis-12 and $2.0 \mathrm{~g}$ trans- 9 , trans- $11 /$ trans- 10 , trans12 of linoleic acid/100 g CLA mixture (data from Rinoru Oil Mills Co. Ltd., Tokyo, Japan). The fatty acid composition of experimental diets is shown in Table 1. Body weight and feed intakes from 11 to $24 \mathrm{~d}$ of age were recorded to determine growth performance.

In experiment 2, forty male chicks ( $8 \mathrm{~d}$ of age, Ross strain) were used. They were randomly assigned to two groups of twenty chicks, with ten replicates of two chicks in a cage, and given either 0 or $10 \mathrm{~g} \mathrm{CLA} / \mathrm{kg}$ diet for $21 \mathrm{~d}$ ad libitum. The basal diet consisted of $452.6 \mathrm{~g}$ maize, $330 \mathrm{~g}$ soyabean meal, $100 \mathrm{~g}$ glucose, $41 \mathrm{~g}$ soyabean oil, $31 \mathrm{~g}$ soya protein, $12 \mathrm{~g} \mathrm{CaCO}_{3}, 18 \mathrm{~g} \mathrm{CaHPO} .2 \mathrm{H}_{2} \mathrm{O}$, $4.3 \mathrm{~g} \mathrm{NaCl}, 3 \mathrm{gtDL}-m$ ethionine, $0 \cdot 1 \mathrm{~g}$ L-threonine, $4 \mathrm{~g}$ vitamin mixture and $4 \mathrm{~g}$ trace mineral mixture $/ \mathrm{kg}$ diet. CLA in the CLA diet replaced part of the soyabean oil contained in the basal diet, which satisfied the nutrient demand for broiler chicks (Japanese Feeding Standard for Poultry, 1997). At 15 and $25 \mathrm{~d}$ of age, the SRBC suspension was injected in the same way as in experiment 1 , and a blood sample was taken via the wing vein at 21 and $29 \mathrm{~d}$ of age. Body weight and feed intake from 8 to $29 \mathrm{~d}$ of age were recorded to determine growth performance. The Animal Care and Use Committee of the Graduate
School of Agriculture of Tohoku University approved all procedures.

\section{Analysis}

Plasma was collected by centrifugation at $500 \mathrm{~g}$ for $10 \mathrm{~min}$. For determination of antibody titres to SRBC, plasma was heated at $56^{\circ} \mathrm{C}$ for $30 \mathrm{~min}$. The plasma samples were stored at $-20^{\circ} \mathrm{C}$ until analysis. Antibody titres to SRBC were determined by the method of Isakov et al. (1982). Briefly two-fold serial dilutions of the tested plasma $(25 \mu \mathrm{l}$ each) were made with the phosphate buffer using ninety-sixwell plates. The wells of plates for determination of total haemagglutinin titres were supplemented with $25 \mu$ l phosphate buffer. The plates were incubated at $37^{\circ} \mathrm{C}$ for $2 \mathrm{~h}$ and placed at $4^{\circ} \mathrm{C}$ overnight. The haemagglutinin titres were expressed as $\log _{2}$ of highest dilution showing visible agglutination. Plasma IgG concentration was determined by single radial immune diffusion methods; briefly, agarose gel $(3: 100, w / v)$ containing rabbit anti-chicken IgG serum was prepared in a plastic container, and $2.5 \mathrm{~mm}$-diameter wells were then punched out of the gel. Plasma samples were placed into each well $(5 \mu \mathrm{l} /$ well $)$. After $48-72 \mathrm{~h}$ at $37^{\circ} \mathrm{C}$ in a humid chamber, the diameters of the precipitin ring were measured with $0.1 \mathrm{~mm}$ accuracy using a calibrated digital viewer. The calibration curve was essentially linear between 0 to $2 \mathrm{mg}$ purified chicken $\mathrm{IgG} / \mathrm{ml}$.

In experiment 1 , a 2 (dietary treatments) by 2 (sexes) ANOVA was applied using SAS (SAS Institute, Cary, NC) with mean separation by Duncan's multiple range test. In experiment 2, the data of body-weight gain, feed intake and weight gain:feed intake ratio were analysed by the Student's test using SAS. For determination of the data of plasma IgG concentration and SRBC titres, a 2 (dietary treatments) by 2 (sampling times) ANOVA was applied using SAS (SAS Institute, Cary, NC) with mean separation by Duncan's multiple range test. In both experiments, the analyses for feed intake, and weight gain:feed intake ratio were based on cage replication. For analyses of data of body-weight gain and plasma $\operatorname{IgG}$ concentration

Table 1. Body-weight gain, feed intake and weight gain:feed intake ratio in male and female chicks fed the experimental diet supplemented with safflower-seed oil (basal) or conjugated linoleic acid (CLA) from 11 to $24 \mathrm{~d}$ of age (experiment 1 ) and those in chicks fed diets containing 0 (basal) or $10 \mathrm{~g} \mathrm{CLA} / \mathrm{kg}$ diet from 7 to $29 \mathrm{~d}$ of age (experiment 2 )

(Mean values with their standard errors for ten chickens)

\begin{tabular}{|c|c|c|c|c|c|c|c|c|c|c|c|c|c|}
\hline \multirow[b]{3}{*}{ Diet } & \multirow[b]{3}{*}{ Sex } & \multicolumn{6}{|c|}{ Experiment 1} & \multicolumn{6}{|c|}{ Experiment 2} \\
\hline & & \multicolumn{2}{|c|}{$\begin{array}{l}\text { Feed intake } \\
(g / 14 d)\end{array}$} & \multicolumn{2}{|c|}{$\begin{array}{l}\text { Body-weight } \\
\text { gain }(g / 14 d)\end{array}$} & \multicolumn{2}{|c|}{$\begin{array}{l}\text { Gain:feed } \\
\text { intake }\end{array}$} & \multicolumn{2}{|c|}{$\begin{array}{l}\text { Feed intake } \\
(\mathrm{g} / 21 \mathrm{~d})\end{array}$} & \multicolumn{2}{|c|}{$\begin{array}{l}\text { Body-weight } \\
\text { gain (g/21 d) }\end{array}$} & \multicolumn{2}{|c|}{$\begin{array}{l}\text { Gain:feed } \\
\text { intake }\end{array}$} \\
\hline & & Mean & SE & Mean & SE & Mean & SE & Mean & SE & Mean & SE & Mean & SE \\
\hline Basal & Male & 1004 & 25 & 586 & 18 & 0.566 & 0.010 & 1420 & 20 & 1008 & 22 & 0.697 & 0.006 \\
\hline CLA & Male & 975 & 16 & 565 & 10 & 0.577 & 0.011 & 1391 & 20 & 997 & 23 & 0.717 & 0.012 \\
\hline Basal & Female & 976 & 23 & 562 & 15 & 0.576 & 0.002 & - & - & - & - & - & - \\
\hline $\begin{array}{l}\text { CLA } \\
\text { Probability }\end{array}$ & Female & 964 & 21 & 556 & 18 & 0.563 & 0.008 & - & - & - & - & - & - \\
\hline Diet & & NS & & NS & & NS & & NS & & NS & & NS & \\
\hline Sex & & NS & & NS & & NS & & - & & - & & - & \\
\hline Diet $\times$ Sex & & NS & & NS & & NS & & - & & - & & - & \\
\hline
\end{tabular}

NS, $P>0.1$. 
and SRBC titres, individual chicks were considered as experimental units.

\section{Results and discussion}

The present experiment showed that chicks fed the CLA diets had higher first haemagglutinin titres against SRBC and IgG concentration in plasma than chicks fed the basal diets containing soyabean oil or safflower-seed oil, irrespective of sex differences or strain (Fig. 1 (A), (B) and (C)). The effects of CLA on humoral immunity were not in agreement among the earlier experiments. Dietary CLA at level of $10 \mathrm{~g} / \mathrm{kg}$ diet enhanced Ig production in immunocompetent organs and plasma IgG concentration in rats (Sugano et al. 1998). Yamasaki et al. (2000) observed that CLA enhanced Ig production in spleen at levels from 0.5 to $5 \mathrm{~g} / \mathrm{kg}$ in diets in a dose-dependent manner, but did not affect serum IgG level in rats. Cook et al. (1993) found that dietary CLA did not affect antibody production to SRBC when chicks fed on a $5 \mathrm{~g}$ lard/ $\mathrm{kg}$ or CLA-supplemented diet for 3 weeks were administrated SRBC into the peritoneal cavity. It has been demonstrated that the route of SRBC injection affects the rate and amount of antibody against SRBC and that the injection of an antigen into the peritoneal cavity has less potency to produce antibodies compared with an injection into the vein (van der Zijpp et al. 1986). Therefore, a reason for the difference in the results between Cook et al. (1993) and the present experiment is probably due to route of antigen administration. Another possible explanation is that dietary CLA concentration or fatty acid composition in the diet used may affect the effect of CLA on antibody production, since the immune modulation effect of CLA was significantly changed by dietary fat sources (Turek et al. 1998). Koga et al. (1997) showed that rats fed a diet containing elaidic acid (trans) produced higher antibody production than rats fed a diet with oleic acid (cis). Thus, it appears that trans-fatty acids including CLA used in the
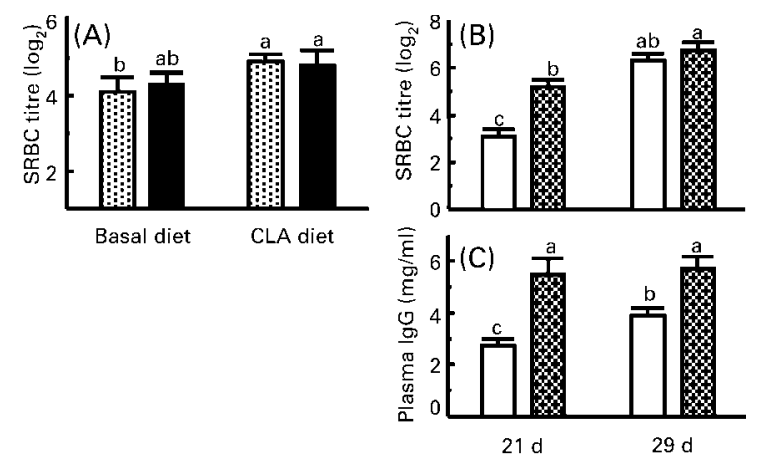

Fig. 1. (A), Antibody titres to sheep erythrocytes (SRBC) in male (घ) and female (回) broiler chicks fed diets supplemented with $10 \mathrm{~g}$ conjugated linoleic acid (CLA) or safflower-seed oil/kg in experiment 1 . Diet effect $P<0.05$, sex effect $P>0.1$, their interaction $P>0.1$. (B), Antibody titres to SRBC with basal diet $(\square)$ and CLA-supplemented diet ( in 21- and 29-d-old chicks (diet effect $P<0.01$, age effect $P<0.05$, their interaction $P<0.1)$ and $(\mathrm{C})$ plasma immunoglobulin $\mathrm{G}$ ( $\mathrm{IgG}$ ) concentration (diet effect $P<0.01$, age effect $P<0.05$, their interaction $P<0.05$ ) in male broiler chicks in experiment 2. $a, b, c$ Mean values with unlike letters were significantly different $(P<0.05)$. Standard errors are represented by vertical bars. present experiment may have the property of enhancing antibody production relative to $c i s$-fatty acids.

The effect of dietary CLA on antibody production reported in the present and some of the previous experiments are comparable with the effects of $n-3$ fatty acids. Fritsche et al. (1991) showed that antibody production against SRBC in chicks fed a fish oil which was relatively rich in eicosapentaenoic acid and docosahexaenoic acid ( $n-3$ polyunsaturated fatty acids) was significantly elevated as compared with that in chicks fed a diet rich in maize oil or rapeseed oil which consists of mainly $n-6$ fatty acids such as linoleic acid. The mode of action of $n-3$ fatty acids has been estimated to be due to changes in prostaglandin $\mathrm{E}_{2}$ or eicosanoid production, which is at least in part induced by changes in fatty acid composition in the plasma membrane (Grimble, 1998). CLA itself hardly becomes incorporated into the phospholipids fraction, suggesting very little effect on eicosanoid production, although Whigham et al. (2002) suggested that dietary CLA reduces antigen-induced eicosanoid release in guinea-pigs. In addition, the effects of CLA on prostaglandin production vary with experimental condition (Li \& Watkins, 1998; Liu \& Belury, 1998; Sugano et al. 1998; Turek et al. 1998; Hayek et al. 1999). Thus the effect of CLA on eicosanoid production is still controversial. It remains to be clarified how CLA affect antibody production.

Feeding CLA at levels of 5 to $10 \mathrm{~g} / \mathrm{kg}$ diet improved feed efficiency, growth and/or meat production in rats, mice and pigs (Chin et al. 1994; Dugan et al. 1997; West et al. 1998; DeLany et al. 1999; Ostrowska et al. 1999; Yamasaki et al. 1999). In contrast to mammals, Szymczyk et al. (2001) observed that feed intake, body-weight gain and feed conversion in chicks fed on diets containing 5 and $10 \mathrm{~g}$ CLA/ $\mathrm{kg}$ diet had no significant effect. The present result of growth performance (Table 1) showed that feeding CLA at a concentration of $10 \mathrm{~g} / \mathrm{kg}$ diet for 2 (experiment 1) or 3 weeks (experiment 2) did not affect body-weight gain, feed intake or feed efficiency. This is similar to the results of Szymczyk et al. (2001). Recently, Du \& Ahn (2002) showed that dietary CLA at levels of 20 and $30 \mathrm{~g} / \mathrm{kg}$ diet for 5 weeks reduced whole fat content without significant reduction in body-weight gain, but feeding $10 \mathrm{~g}$ CLA $/ \mathrm{kg}$ diet for 3 weeks did not affect growth, abdominal and whole fat content in broiler chicks. This suggests that dietary CLA is less effective in changing body composition in chickens. Pariza et al. (2001) noted that the cis-9/trans-11 CLA isomer which enhances growth and probably feed efficiency in young rodents, and the trans-10/cis-12 CLA isomer which changes body composition use separate biochemical mechanisms. Therefore, feeding periods, dietary concentration, and type of isomer of CLA may be factors affecting growth performance and body fat content.

In conclusion, dietary CLA ( $10 \mathrm{~g} / \mathrm{kg}$ diet $)$ enhances antibody production in broiler chickens, regardless of sex, strain of chicks and dietary fat sources.

\section{References}

Chew BP, Wong TS, Shultz TD \& Magnuson N (1997) Effects of conjugated dienoic derivatives of linoleic acid and beta-carotene in modulating lymphocyte and macrophage function. Anticancer Research 17, 1099-1106. 
Chin SF, Storkson JM, Albright KJ, Cook ME \& Pariza MW (1994) Conjugated linoleic acid is a growth factor for rats as shown by enhanced weight gain and improved feed efficiency. Journal of Nutrition 124, 2344-2349.

Cook ME, Miller CC, Park Y \& Pariza M (1993) Immune modulation by altered nutrient metabolism: nutritional control of immune-induced growth depression. Poultry Science 72, $1301-1305$.

Du M \& Ahn DU (2002) Effect of dietary conjugated linoleic acid on the growth rate of live birds and the abdominal fat content and quality of broiler meat. Poultry Science 81, 428-433.

DeLany JP, Blohm F, Truett AA, Scimeca JA \& West DB (1999) Conjugated linoleic acid rapidly reduces body fat content in mice without affecting energy intake. American Journal of Physiology 276, R1172-R1179.

Dugan MER, Alhus JL, Schaefer AL \& Kramer JKG (1997) The effect of conjugated linoleic acid on fat to lean repartitioning and feed conversion in pigs. Canadian Journal of Animal Science 77, 723-725.

Fritsche J \& Steinhart H (1998) Analysis, occurrence, and physiological properties of trans fatty acids (TFA) with particular emphasis on conjugated linoleic isomers (CLA) - a review. Fett Wissenschaft Technologie 100, 190-220.

Fritsche KL, Cassity NA \& Waksmann BH (1991) Effect of dietary fat source on antibody production and lymphocyte proliferation in chickens. Poultry Science 70, 611-617.

Grimble RF (1998) Dietary lipids and the inflammatory response. Proceeding of the Nutrition Society 57, 535-542.

Hayek MG, Han SN, Wu D, Watkins BA, Meydan M, Dorsey JL, Smith DE \& Meydani SN (1999) Dietary conjugated linoleic acid influences the immune response of young and old C57BL/6NCrlBR mice. Journal of Nutrition 129, 32-38.

Isakov N, Feldmann M \& Segal S (1982) The mechanism of modulation of humoral immune responses after injection of mice with lactic dehydrogenase virus. Journal of Immunology 128, 969-975.

Japanese Feeding Standard for Poultry (1997) Japanese Feeding Standard for Poultry [Agriculture, Forestry and Fisheries Research Council Secretariat, editors]. Tokyo, Japan: Agriculture, Forestry and Fisheries Research Council Secretariat.

Koga T, Nonaka M, Gu JY \& Sugano M (1997) Linoleic and alpha-linolenic acids differently modify the effects of elaidic acid on polyunsaturated fatty acid metabolism and some immune indices in rats. British Journal of Nutrition 77, 645-656.

Li Y \& Watkins BA (1998) Conjugated linoleic acids alters bone fatty acid composition and reduce ex vivo prostaglandin E2 biosynthesis in rats fed n-6 or n-3 fatty acids. Lipids 33, 417-425.

Liu KL \& Belury MA (1998) Conjugated linoleic acid reduces arachidonic acid content and PGE2 synthesis in murine keratinocytes. Cancer Letters 127, 15-22.

Miller CC, Park Y, Pariza MW \& Cook ME (1994) Feeding conjugated linoleic acid to animals partially overcomes catabolic responses due to endotoxin injection. Biochemical and Biophysics Research Communication 198, 1107-1112.
Ostrowska E, Muralitharan M, Cross RF, Bauman DE \& Dunshea FR (1999) Dietary conjugated linoleic acids increase lean tissue and decrease fat deposition in growing pigs. Journal of Nutrition 129, 2037-2042.

Pariza MW, Park Y \& Cook ME (2000) Mechanisms of action of conjugated linoleic acid: evidence and speculation. Proceedings of Society Experimental Biology and Medicine 223, 8-13.

Pariza MW, Park Y \& Cook ME (2001) The biologically active isomers of conjugate linoleic acid. Progress in Lipid Research 40, 283-298.

Park Y, Albright KJ, Storkson JM, Cook ME \& Pariza MW (1997) Effect of conjugated linoleic acid on body composition in mice. Lipids 32, 853-858.

Stangl GI (2000) Conjugated linoleic acids exhibit a strong fat to lean partitioning effect, reduce serum VLDL lipids and redistribute tissue lipids in food-restricted rats. Journal of Nutrition 130, 1140-1146.

Sugano M, Tsujita A, Yamasaki M, Noguchi M \& Yamada K (1998) Conjugated linoleic acid modulates tissue levels of chemical mediators and immunoglobulins in rats. Lipid 33, $521-527$.

Szymczyk B, Pisulewski PM, Szczurek W \& Hanczakowski P (2001) Effects of conjugated linoleic acid on growth performance, feed conversion efficiency, and subsequent carcass quality in broiler chickens. British Journal of Nutrition 85, $465-473$

Takahashi K, Kawamata K, Akiba Y, Iwata T \& Kasai M (2002) Influence of dietary conjugated linoleic acid isomers on early inflammatory responses in male broiler chickens. British Poultry Science 43, 47-53.

Turek JJ, Li Y, Schoenlein IA, Allen KGD \& Watkins BA (1998) Modulation of macrophage cytokine production by conjugated linoleic acids is influenced by the dietary n-6:n-3 fatty acid ratio. Journal of Nutritional Biochemistry 9, 258-266.

van der Zijpp AJ, Scott TR \& Glick B (1986) The effect of different routes of antigen administration on the humoral immune response of the chick. Poultry Science 65, 809-811.

West DB, DeLany JP, Camet PM, Blohm F, Truett AA \& Scimeca BA (1998) Effects of conjugated linoleic acid on body fat and energy metabolism in mice. American Journal of Physiology 144, R667-R672.

Whigham LD, Higbee A, Bjorling DE, Park Y, Pariza MW \& Cook ME (2002) CLA reduces antigen-induced eicosanoid release in conjugated linoleic acid-fed guinea pigs. American Journal of Physiology 282, R1104-R1112.

Wong MW, Chew BP, Wong TS, Hosick HL \& Shultz TD (1997) Effects of dietary conjugated linoleic acid on lymphocyte function and growth of mammary tumors in mice. Anticancer Research 17, 987-993.

Yamasaki M, Kishihara K, Mansho K, Ogino Y, Kasai M, Sugano M, Tachibana H \& Yamada K (2000) Dietary effect of conjugated linoleic acid increases immunoglobulin productivity of Sprague-Dawley rat spleen lymphocytes. Bioscience Biotechnology and Biochemistry 64, 2159-2164. 